\title{
ПРОМИСЛОВИЙ ТУРИЗМ ЯК ПЕРСПЕКТИВНИЙ ВЕКТОР РОЗВИТКУ ТУРИСТИЧНИХ ДЕСТИНАЦІЙ ДЛЯ ІНДУСТРІАЛЬНИХ РЕГІОНІВ
}

\section{INDUSTRIAL TOURISM AS A PROSPECTIVE VECTOR OF DEVELOPMENT OF TOURIST DESTINATIONS FOR INDUSTRIAL REGIONS}

\author{
Касенкова Катерина Віталіївна \\ аспірант, \\ Харківський національний економічний університет \\ імені Семена Кузнеця \\ ORCID: https://orcid.org/0000-0002-8310-1311 \\ Kasenkova Kateryna \\ Simon Kuznets Kharkiv National University of Economics
}

\begin{abstract}
В статі розглянуто основі аспекти промислового туризму, та загальний досвід різних країн в контексті використання промислового туризму для розвитку туристичних атракцій. Розглянуто основні підходи до промислового туризму зарубіжними та вітчизняними науковцями. Для визначення попиту на відвідування компаній були проаналізовані різні національні та місцеві джерела. Визначено, що розвиток цього виду туризму має сенс в межах промислових регіонів, де спостерігається високий ступінь антропогенної трансорормації природних ландшафртів, різноманітна мережа діючих промислових підприємств та збережених об'єктів промислової спадщини. Визначено основні проблеми, що заважають розвитку промислового туризму в цілому, та на окремих підприємствах зокрема. Для деяких організацій високі витрати на розвиток, пов'язані із впровадженням промислового туризму, призводять до того, що вони вирішують не впроваджувати подібні проекти.
\end{abstract}

Ключові слова: промисловий туризм, маркетинг територій, регіональний розвиток, об'єкти промислового туризму.

В статье рассмотрены основные аспекты промышленного туризма, и общий опыт различных стран в контексте использования промышленного туризма для развития туристических достопримечательностей. Рассмотрены основные подходы к промышленному туризму зарубежными и отечественными учеными. Для определения спроса на посещение компаний были проанализированы различные национальные и местные источники. Дана общая оценка потенциала внедрения элементов промышленного туризма для развития индустриальных регионов. Проанализирован в ретроспективе опыт использования концепции промышленного туризма. Развитие этого вида туризма имеет смысл в пределах промышленных регионов, где наблюдается высокая степень антропогенной трансформации природных ландшафтов, разнообразная сеть действующих промышленных предприятий и сохранившихся объектов промышленной наследия. Таким образом, для промышленных регионов и дестинаций Украины промышленный туризм имеет значительные преимущества по сравнению с другими видами туризма. Проведен анализ тенденций и особенностей развития индустриального туризма в контексте разных стран. Определены общие перспективы развития индустриального туризма - учитывая страны, из которых приезжают туристы, оказалось, что особенно в Азии, на Ближнем Востоке и в Африке ежегодные темпы роста высоки, что в среднем составляет 3,6 процента. Определено, что несмотря на все требования к развитию промышленного туризма, стоит отметить, что он имеет большой потенциал для местного региона или отдельной туристической дестинации. Преимущества заключаются в следующем: косвенная занятость, созданная за счет мультипликативного эффректа, вызванного повышенным спросом на товары и услуги. Определены основные проблемы, мешающие развитию промышленного туризма в целом, и на отдельных предприятиях в частности. Для некоторых организаций высокие расходы на развитие, связанные с внедрением промышленного туризма, приводят к тому, что они решают не внедрять подобные проекты.

Ключевые слова: промышленный туризм, маркетинг территорий, региональное развитие, объекты промышленного туризма. 
The article considers the aspects of industrial tourism, and the general experience of different countries in the context of the use of industrial tourism for the development of tourist attractions. The main approaches to industrial tourism by foreign and domestic scientists are considered. Various national and local sources were analyzed to determine the demand for company visits. The general estimation of potential of introduction of elements of industrial tourism for development of industrial regions is given. The experience of using the concept of industrial tourism is analyzed in retrospect. The development of this type of tourism makes sense within industrial regions, where there is a high degree of anthropogenic transformation of natural landscapes, a diverse network of existing industrial enterprises and preserved industrial heritage sites. Thus, for industrial regions and destinations of Ukraine, industrial tourism has significant advantages over other types of tourism. The analysis of tendencies and features of development of industrial tourism in the context of different countries is carried out. The general prospects for the development of industrial tourism have been identified - taking into account the countries from which tourists come, it turned out that especially in Asia, the Middle East and Africa, annual growth rates are high, averaging 3.6 percent. It is determined that despite all the requirements for the development of industrial tourism, it should be noted that it has great potential for a local region or a particular tourist destination. The advantages are as follows: indirect employment, created due to the multiplier effect caused by increased demand for goods and services. The main problems that hinder the development of industrial tourism in general, and at individual enterprises in particular, have been identified. For some organizations, the high development costs associated with the introduction of industrial tourism lead to the fact that they decide not to implement such projects.

Keywords: industrial tourism, territory marketing, regional development, industrial tourism objects.

Постановка проблеми. На сучасному етапі становлення туристичного ринку існує потреба у розвитку внутрішнього туризму в Україні, спираючись на місцеві ресурси регіонів. При потужній конкуренції в туристичному бізнес-середовищі виникає проблема пошуку нових джерел та ресурсів для туризму та пропозицій інноваційних туристичних послуг.

Одним із шляхів вирішення проблем розвитку туризму в регіоні може стати використання нетрадиційних для сорери туризму можливостей території, що призведе до фрормування нових видів туризму. Промисловий туризм $€$ одним із сучасних напрямків і має потенціал для створення унікального досвіду, поєднуючи знання, почуття та емоції. В Україні потенціал промислового туризму, його особливість та привабливість ще не визнані.

Аналіз останніх публікацій по проблемі. Теоретичні основи концепції промислового туризму вивчалися в роботах таких вчених, як Е.А. Фрю [1], Дж.Е. Едвардс [2], Дж.Дж. Хосперс [3]. Питання, що стосуються досліджень промислової спадщини в Україні, розглядались у працях Н.Д. Свірідовової [4], В.О. Сорочан [5] та в інших.

Формулювання цілей дослідження. Метою дослідження $€$ теоретичне обґрунтування та визначення перспектив розвитку промислового туризму як способу підвищення привабливості промислових регіонів. Узагальнення змісту промислового туризму щодо існуючих підходів до його визначення.

Виклад основних результатів та їх обґрунтування. Однією з перших ідей щодо сприяння відвідуванню діючих підприємств була в 1988 році: цього року Британський туристичний орган розпочав рекламну кампанію під назвою «Побачити галузь в роботі». Ця подія надихнула інші країни, регіони та міста на використання подібного підходу для просування промислового туризму. Наприклад, наприкінці 90-х років місто Роттердам у Нідерландах створило тур з промислового туризму.

Пізніше, у 2000 році, у графстві Йорк, штат Пенсільванія, було представлено власну торгову марку під назвою «Factory Tour Capital of the World», що фрункціонує і до сьогодення [6].

Через рік, у 2001 році, регіон Луари у Франції заснував організацію під назвою «Відвідайте наші компанії». Головною метою цієї організації було покращення пропозиції промислового туризму. У 2005 році в Шанхаї було створено центр сприяння розвитку промислового туризму.

Тоді ж в Туріно в Італії було розроблено та впроваджено програму під назвою «Зроблено в Торіно» У 2006 році фрранцузьке місто Анже в регіоні Луара організувало першу європейську конференцію з питань відвідування компаній. Учасники конференції були зосереджені на можливостях промислового туризму як для підприємств, так і для сільських або мегаполісів, в яких вони знаходяться.

Такі міста та регіони, як Амстердам (Нідерланди), Нагоя (Японія), регіон Рона-Альпи (Франція) та Західна Австралія є прикладами регіонів з програмами промислового туризму.

Протягом розвитку та становлення промислового туризму компанії застосовували різні підходи до промислового туризму (див. табл. 1).

Відповідно до сучасного підходу підприємства у промисловому туризмі можуть бути як неактивними, так і активними. Неактивні компанії означає, що вони взагалі не хочуть при- 


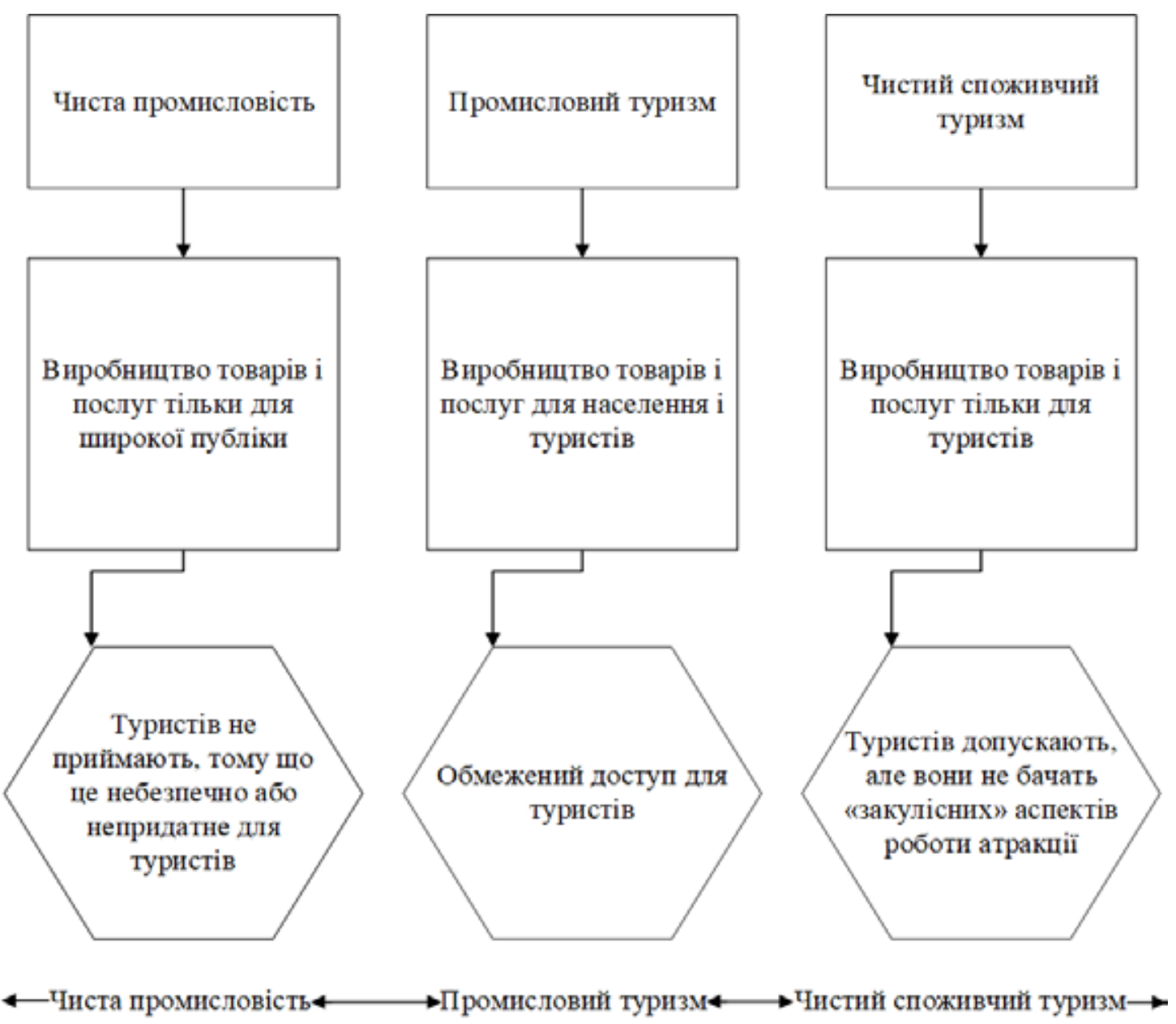

Рис. 1. Характеристика промислового туризму порівняно з «чистими» галузями промисловості та туризму

Джерело: розроблено автором за [1]

ймати промислових туристів. Причиною цього можуть бути обмеження безпеки компанії чи щось інше. Активні компанії можуть бути, 3 одного боку, реактивними чи активними, 3 іншого. Приймаючі компанії, які застосовують ініціативний підхід, сприймають промисловий туризм як джерело доходу, інструмент маркетингу та зв'язки 3 громадськістю. Однак компанії з реактивним підходом відкривають свої двері лише у відповідь на запити. Це - характеристики реактивного та активного підходу в промисловому туризмі.

У наш час велике значення набуває пошук нових можливостей для розвитку туризму в межах промислових регіонів, де спостерігається високий ступінь антропогенної трансфрормації природних ландшафртів, різноманітна мережа діючих промислових підприємств та збережених об'єктів промислової спадщини. Таким чином, для промислових регіонів України промисловий туризм має свої переваги.
Вивчаючи поняття промислового туризму, необхідно мати на увазі його взаємозв'язок 3 іншими видами туризму. Промисловий туризм можна розглядати як форму туризму з особливим інтересом; це означає, що туристи подорожують, поки у них є певний інтерес, який можна вгамувати, відвідавши певний регіон.

Будучи різновидом туризму з особливим інтересом, промисловий туризм може бути пов'язаний $з$ освітнім туризмом, культурним та спадковим туризмом, який охоплює промислову спадщину, сільськогосподарський, фермерський та виноробний туризм.

Промисловий туризм дає можливості не лише окремим компаніям, а й загалом туристичним дестинаціям. Це актуально особливо для міст, що мають значну промислову базу, промисловий туризм охоплює великі можливості для зміцнення економічної структури, тобто пряму та непряму зайнятість; та збільшити пропозицію туристичних продуктів [8]. 
Таблиця 1

Основні підходи до промислового туризму

\begin{tabular}{|c|c|c|}
\hline Рік & Автор & Концепція \\
\hline 2000 рік & Е. Фрю & $\begin{array}{l}\text { Фрю здійснила дисреренціацію між чистою промисловістю, } \\
\text { промисловим туризмом та чисто споживчим туризмом (див. рис. 1) } \\
\text { Чиста промисловість означає, що відвідування заборонено, } \\
\text { наприклад, через деякі обмеження безпеки. Промисловий } \\
\text { туризм означає обмежений доступ до підприємств для туристів. } \\
\text { Споживчий туризм означає доступ лише для туристів. }\end{array}$ \\
\hline 2001 рік & $\begin{array}{l}\text { А. Штайнек } \\
\text { [7] }\end{array}$ & $\begin{array}{l}\text { Штайнек представив типологію промислового туризму що } \\
\text { варіюється від місця розташування до місць призначення. }\end{array}$ \\
\hline 2006 рік & Жан-Рене Моріс & $\begin{array}{l}\text { Моріс виділив три концепції туристичного відвідування компаній: } \\
\text { 1) Відкриті двері. Компанії, які організують «день відкритих } \\
\text { дверей», не змінюючи свої виробничі підрозділи. В цілому, } \\
\text { персонал піклується про те, щоб направляти відвідувачів. Ці } \\
\text { фрірми просто показують, як вони працюють. } \\
\text { 2) Комунікаційні центри. Компанії, які продублювали свої } \\
\text { виробничі підрозділи в спеціально розроблених візит-центрах. } \\
\text { Відвідувачів часто супроводжують професійні гіди. Візити в } \\
\text { компанію розглядаються як засіб спілкування. } \\
\text { 3) Комерційні об'єкти. Компанії, які розглядають відвідування } \\
\text { як комерційну діяльність. Вони відкривають магазин і / або інші } \\
\text { торгові об'єкти поруч з виробничим майданчиком. }\end{array}$ \\
\hline
\end{tabular}

Джерело: розроблено автором за [1; 7]

Більше того, для міста зі значною промисловою базою промисловий туризм може стати потенційним сектором зростання, який відповідає його ідентичності: цей вид туризму надає можливості для посилення самобутності та іміджу міста, особливо, спираючись на його наявні активи. Слід зазначити, що більшість міст, однак, мають активи для розвитку промислового туризму, але не можуть їх використати.

Незважаючи на всі вимоги до розвитку промислового туризму, варто зазначити, що він має великий потенціал для вигоди для місцевого регіону. Переваги полягають у наступному: непряма зайнятість, створена за рахунок мультиплікативного ефекту, спричиненого підвищеним попитом на товари та послуги. Існування екскурсій може спонукати туристів збільшити тривалість перебування в регіоні. Залишаючись на довший період у регіоні, туристи витратять більше грошей на місцеві підприємства. За умови успішного розвитку туризму позитивний імідж регіону буде зростати, i, ймовірно, це може допомогти залучити потенційних роботодавців до регіону.

Сьогодні багато вчених та профресіоналів стверджують, що попит на промисловий туризм буде зростати. Основним аргументом цього $€$ зміна тенденцій у туризмі.

Першою причиною цього $є$ те, що туристична галузь швидко розвивається через глобалізаційний світ, який дає все більше і більше можливостей людям подорожувати.
Враховуючи країни, 3 яких приїжджають туристи, виявилося, що особливо в Азії, на Близькому Сході та в Асрриці щорічні темпи зростання високі, що в середньому становить 3,6 відсотка. Світова туристична організація стверджує, що подальше зростання туристичної індустрії становитиме понад 1,5 мільярда прибулих у 2030 році [9].

Країни Західної Європи відносяться до найбільш зрілих ринків походження для туристів у всьому світі: широкий спектр людей з усіх соціальних класів займається туризмом. Зростання середньої заробітної плати та дозвілля разом із зменшенням витрат на поїздки та підвищення рівня власності автомобілів призводять до зростання попиту на відпочинок, цей процес можна спостерігати в Європі протягом останніх десятиліть. Отже, це причина, чому туризм зазвичай сприймається як одна з галузей економіки, яка має реальний потенціал для подальшого зростання за короткий час.

Туристи стали більш зрілими і їхні вимоги зростають: коли туристи відвідують більшість досить традиційних туристичних об'єктів, таких відомих міст, як Рим, Париж або Берлін, вони шукають більш екзотичні місця, які $€$ далеко від так званих визначних пам'яток. Особливо міста, в яких пропонується альтернативний асортимент визначних пам'яток, як-от об'єкти промислового туризму, можуть бути цікавими для туриста, який вже бачив більшість визначних пам'яток, які необхідно відвідати. 
Очікується, що в майбутньому туристи більше звертатимуть свою увагу на одноцільні візити, тобто відвідування місць та визначних пам'яток, які враховують їхні конкретні потреби та інтереси.

На жаль, Світова туристична організація $\mathrm{OOH}$ не надає жодної інорормації про попит на відвідування компаній чи промисловий туризм. Для визначення попиту на відвідування компаній були проаналізовані різні національні та місцеві джерела [10].

Наприклад, у 2004 році в Новому Південному Уельсі в Австралії понад 10 відсотків туристів відвідали об'єкти промислового туризму. Більше того, майже 8 мільйонів людей відвідали промислові визначні пам'ятки Франції тогож року. У Великобританії промисловий туризм залучав майже п'ять мільйонів відвідувачів на рік у 1989 році. У 1990 році у Великобританії було 294 компанії, які відкрили свої двері для відвідувачів; ці компанії становили близько 6 відсотків усіх британських туристичних визначних пам'яток.

У наведеній нижче таблиці (табл. 2) подано огляд деяких об'єктів промислового туризму в США, Великобританії та Японії, а також наведено кількість відвідувачів, що дає уявлення про частку промислового туризму.

Цифри, наведені у наведеній вище таблиці, стверджують, що попит на промисловий туризм є не лише з боку декількох груп інтересів, але й з боку широкої громадськості.

Більше того, можна помітити, що не тільки популярні та привабливі споживчі товари, такі як шоколад чи машини, можуть залучити велику кількість відвідувачів. Великий інтерес відвідувачів також спрямовується на «бізнес для бізнесу», наприклад, компанії з виробництва ядерного палива або канатів.

Висновки та перспективи подальших досліджень. Виходячи 3 кількості та типу об'єктів промислового туризму, що існують у всьому світі, та кількості відвідувачів цих визначних пам'яток, виявляється, що туристи зацікавлені в огляді промисловості або зацікавлені в спостереженні за тим, як працюють інші люди.

3 точки зору відвідувача, об'єкт промислового туризму може забезпечити якийсь фрізичний досвід. Туристам цікаво відвідувати визначні пам'ятки, які надають досвід, де вони мають можливість певною мірою бути залученими, а об'єкт промислового туризму надає туристам цю можливість.

Однак існують деякі проблеми в розвитку промислового туризму. Для деяких організацій високі витрати на розвиток, пов'язані із впровадженням промислового туризму, призводять до того, що вони вирішують не відкривати свої двері для громадськості [11].

Більше того, розвиток невеликого туру для відвідувачів призводить до необхідності забезпечити необхідну інфрраструктуру: туалети, зону прийому та автостоянку. Для успішних промислових турів, які будуть популярні серед туристів, потрібні закусочні, магазини, оглядові галереї та виставки. Більшість підприємств просто не розроблені для відвідувачів, тому існують логістичні та безпекові перешкоди, які потрібно подолати.

Більше того, необхідно мати належне страхування відповідальності, щоб покрити ризик травмування відвідувачів під час перебування на підприємстві. Згадані вище пункти ілюструють важливість розвитку промислового туризму контрольованим та планомірним шляхом для подолання цих перешкод. Однак деякі промислові визначні пам'ятки були побудовані з передбаченим доступом відвідувачів та включали зроблені доріжки та оглядові галереї.

Існує можливість крадіжки та втручання туристів у промислові визначні місця. Більше того, існує ризик порушення безпеки та промис-

Вибір визначних пам'яток Великобританії, Японії та США

Таблиця 2

\begin{tabular}{|c|l|c|}
\hline Країна & \multicolumn{1}{|c|}{ Залучення промислового туризму } & $\begin{array}{c}\text { Відвідувачів на рік } \\
\text { (в тис.) }\end{array}$ \\
\hline Об'єднане Королівство & Cadbury World (шоколадна орабрика) & 400 \\
\hline Японія & Тоуота Motor Corporation (автоконцерн) & 300 \\
\hline США & $\begin{array}{l}\text { Бен і Джеррі Домашнє (виробництво } \\
\text { морозива) }\end{array}$ & 170 \\
\hline США & Веджвуд (гончарна фрабрика) & 100 \\
\hline США & $\begin{array}{l}\text { Британське ядерне паливо (очищення } \\
\text { ядерних об'єктів) }\end{array}$ & 100 \\
\hline США & WR Outhwaite and Son & $75-100$ \\
\hline США & Олівці Камберленд & 64 \\
\hline
\end{tabular}


лового шпигунства. Деякі галузі можуть вирішити не розвивати промислові тури, оскільки вважають, що виробничий процес не $є$ візуально привабливим для туристів. Крім того, це може також стосуватися проблем виробничих відносин між компаніями, співробітники яких працюють за відрядною ставкою, оскільки проведення екскурсій може перервати виробничий процес і негативно вплинути на певний персо- нал, який повинен пристосувати схеми роботи відповідно до відвідувачів. Для підприємств, які працюють, щоб виконати важливе замовлення, регулярні туристичні групи на фрабриці можуть уповільнити виробничий процес.

Отже для есрективного розвитку туристичній дестинації необхідно розробити загальну концепцію стратегії між представниками промисловості та влади.

\section{СПИСОК ВИКОРИСТАНИХ ДЖЕРЕЛ:}

1. Frew E.A. Industrial tourism: a conceptual and empirical analysis : PhD Thesis, Victoria University, 2016. 305 p.

2. Edwards J.A., Coit J.C.L. Mines and quarries: Industrial heritage tourism : Annals of tourism research, 1996.

№ 2. P. 351-363.

3. Hospers G. J. Industrial heritage tourism and regional restructuring in the European Union : European Planning Studies, 2002. № 3. P. 397-404.

4. Свірідова Н.Д. Індустріальний туризм: теоретичні аспекти. Географрія та туризм. 2010. № 10. С. 8-15.

5. Сорочан В.О. Аналіз ринку послуг промислового туризму в Україні. Актуальні проблеми економіки. 2015. № 12. C. 136-145.

6. York County - Factory Tour Capital of the World Attraction Details. URL: http://explorepahistory.com/attraction. php?id=1-B-31F1 (дата звернення: 15.05.2021).

7. Steinecke A. Kulturtourismus in der Erlebnisgesellschaft. Trends-Strategien-Erfolgsfaktoren : Geographie und Schule, 2002. № 135. P. 10-14.

8. Пацюк В.С. Індустріальний туризм і перспективи його розвитку в Україні. Наукові записки Вінницького ДПУ ім. М. Коцюбинського. Серія : Географрія. 2008. Випуск 15. 55 с.

9. Akhmedova O. European Industrial Tourism: Lessons for Ukraine : Назустріч викликам співробітництва між Україною та ЄС: досвід центрів ім. Жана Моне в Києві та Маріуполі : Матеріали Міжнародної науково-практичної конференції, м. Маріуполь, 2015 р. ДонДУУ, Маріуполь, 2015. С. 143-149.

10. Свірідова Н.Д. Роль та значення індустріального туризму для соціально-економічного розвитку регіону. Український Часопис - XXI. 2010. № 9(10). С. 30-32.

11. Bowen R. L. et al. The interface between tourism and agriculture : Journal of Tourism Studies, 1991. № 2. P. 43-54.

\section{REFERENCES:}

1. Frew E.A. (2000) Industrial tourism: a conceptual and empirical analysis. PhD Thesis, Victoria University, 305.

2. Edwards J.A., Coit J.C.L. (1996) Mines and quarries: Industrial heritage tourism. Annals of tourism research, 2, 351-363.

3. Hospers G.J. (2002) Industrial heritage tourism and regional restructuring in the European Union. European Planning Studies, 3, 397-404.

4. Sviridova N.D. (2010) Industrial tourism: theoretical aspects. Geography and tourism, 10, 8-15. URL: http://nbuv.gov.ua/UJRN/gt_2010_10_4

5. Sorochan V.O. (2015) Analysis of the market of industrial tourism services in Ukraine. Actual problems of economy, 12, 136-145.

6. York County - Factory Tour Capital of the World Attraction Details. URL: http://explorepahistory.com/ attraction. php?id=1-B-31F1

7. Steinecke A. (2002) Kulturtourismus in der Erlebnisgesellschaft. Trends-Strategien-Erfolgsfaktoren. Geographie und Schule, 135, 10-14.

8. Patsiuk V.S. (2008) Industrialnyy turyzm i perspektyvy y̌ho rozvytku v Ukraïni. Naukovi zapysky Vinnytskoho DPU im. M.Kotsiubynskoho. Seriia: Heohrafiia, 15, 55.

9. Akhmedova O. (2015) European Industrial Tourism: Lessons for Ukraine. Nazustrich vyklykam spivrobitnytstva mizh Ukrainoiu ta YeS: dosvid tsentriv im. Zhana Mone v Kyievi ta Mariupoli, 143-149.

10. Sviridova N.D. (2010) Rol ta znachennia industrialnoho turyzmu dlia sotsialno-ekonomichnoho rozvytku rehionu. Ukraïnskyy Chasopys, 9(10), 30-32.

11. Bowen R.L. (1999) The interface between tourism and agriculture. Journal of Tourism Studies, 2, 43-54. 